\title{
A FELTÉTELES ÖNBECSÜLÉS SKÁLA (CSES-H) MAGYAR VÁLTOZATÁNAK VALIDÁLÁSA ÉS PSZICHOMETRIAI JELLEMZÖI
}

\author{
SÁGI ANDREA \\ ELTE, PPK, Személyiség- és Egészségpszichológia Tanszék \\ E-mail: andi.sag@gmail.com \\ Beérkezett: 2014. január 25. - Elfogadva: 2015. április 25.
}

\begin{abstract}
Elméleti háttér: Az önbecsülés alapvető pszichológiai szühséglet, de egyes típusainak a mentális egészség szempontjából nemcsak jó, hanem káros következményei is lehetnek. A feltételes önbecsülés az alacsony alapönbecsülésből és különböző énmegerösítő szükségletekből (kompetencia és kapcsolatok) származik, negatívan korrelál a mentális egészség indikátoraival és számos negatív pszichológiai jellemzövel jár együtt.

Cél: A Feltételes Önbecsülés Skála magyar változata (CSES-H) pszichometriai jellemzőinek vizsgálata több független mintán.

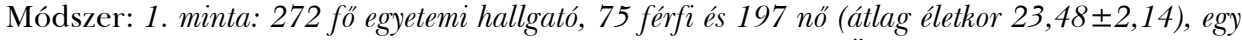
hónappal késöbb 153 fö töltötte ki a következö kérdöíveket: Feltételes Önbecsülés Kérdöív (CSES-H), Rosenberg-féle Önbecsülés Skála (RSES), Önegyüttérzés Skála (SCS-H), Spielberger-féle Vonásszorongás Skála (STAI-T), Beck Depresszió Kérdöív (BDI), Diszpozicionális Optimizmus Kérdöív (LOT-R).

A 2. mintában rendszeresen táncoló 162 fó, 52 férfi és 110 nö (átlag életkor 28,5 \$8,59) és 208 aerobikozó nö (átlag életkor 28,4 $\pm 8,46$ ) töltötte ki a következö kérdöiveket: CSES-H, RSES, WHO Jóllét Kérdöív rövidített változat (WHO-5), Röviditett Pozitív és Negatív Affektivitás Skála (PANAS).

Eredmények: A Feltételes Önbecsülés Skála és két skálája jó reliabilitás értékeket (0,72 és 0,91 között) és teszt-reteszt reliabilitást (0,74-0,79), a megerösito” faktorelemzés pedig elfogadható mértéku" illeszkedést mutatott. A feltételes önbecsülés a globális önbecsüléssel, az önegyüttérzéssel, a diszpozicionális optimizmussal, a jólléttel és a pozitív affektivitással negatívan, míg a vonásszorongással, a depresszióval és a negatív affektivitással pozitívan korrelált.

Következtetések: A Feltételes Önbecsülés Skála magyar változatának pszichometriai jellemzői megfelelöek.
\end{abstract}

Kulcsszavak: feltételes önbecsülés, feltételes önbecsülés skála, pszichometriai jellemzők 


\section{BEVEZETÉS}

\section{A feltételes önbecsülés fogalma}

Az önértékelés, önbecsülés témakörén belül a tudományos érdeklődés fókuszában az önbecsülés feltételes, illetve más néven kiérdemelt (JOHNSON és FORSMAN, 1995) formáinak területspecificitása (kompetenciaalapú, szociális tetszés alapú stb.) áll. (V. KoMLósI, 2007). A feltételes (valamitől függő) önbecsülés az alacsony alap ${ }^{1}$ önbecsülésből és különböző én-megerősítő szükségletekből (kompetencia és kapcsolatok) fakadó szerkezetként definiálható (JOHNSON és BLOM, 2007). A nemfeltételes alapönbecsülés elégtelensége a gyökere a feltételes önbecsülésnek (FORSMAN és JOHNSON, 1996).

A feltételes önbecsülés a személy észlelt önértékének különböző külső bázisára vagy forrásaira vonatkozik (CROCKER és WOLFE, 2001; RYAN és DeCI, 2000). Széles körű az egyetértés abban, hogy az emocionális támogatásból, mások értékeléséből és a kompetenciából származó feltételes önbecsülés megbízhatatlan és sérülékeny bázisa az önbecsülésnek (CROCKER, 2002; JOHNSON és FORSMAN, 1995).

\section{Az alap-és feltételes önbecsülés modellje}

A fogalom megértéséhez röviden meg kell ismerkednünk JOHNSON és FORSMAN (1995) önbecsülés modelljével. A szerzők különbséget tesznek az önbecsülés két független aspektusa a nem-feltételes, alapvető és a feltételes (kiérdemelt) önbecsülés között (FORSMAN és JOHNSON, 1996). Az alapvető önbecsülés az elemi késztetések elfogadásának képessége, amelyre kora gyerekkorban a szülők feltétel nélküli szeretetén és a biztonságos kötődésen (BOWLBY, 1980) keresztül teszünk szert (FORSMAN és JOHNSON, 1996; ROGERS, 1951). Stabilnak tekinthető, külső visszajelzések, események nem befolyásolják (JOHNSON, 1998; JOHNSON és FORSMAN, 1995), és vonás jelleggel lesz meghatározó a személyiségre nézve a későbbi életében.

Ezzel szemben a feltételes vagy kiérdemelt önbecsülés a későbbi fejlődésben szerzett jellemző, amiért meg kell dolgoznunk (Forsman és JOHNSON, 1996; FRANKS és MAROLLA, 1976; HARTER, 1985): bizonyos erőfeszítéseink, vagy mások elvárása szerinti magatartásunk révén „elnyert” önbecsülés. JOHNSON (1997) és CROCKER (2006) úgy fogalmaznak, hogy az önbecsülés nem csak valami, amit birtoklunk, hanem valami, amire törekszünk is.

A vizsgálatok azt mutatták (JOHNSON és FORSMAN, 1995; JOHNSON és PATChING, 2013), hogy a kompetenciaalapú és mások értékelésével kiérdemelt önbecsülés csak akkor maladaptív, ha alacsony alapönbecsüléssel kombinálódik. Az én-szerkezet ezen fajtájához önkritika, ellenségesség, „toxikus” teljesítményre törekvés, perfekcionizmus, teljesítményszorongás, gyenge egészségi állapot és testi tünetek kapcsolódnak (JOHNSON, 2002; JOHNSON, 2010; JOHNSON, PAANANEN,

\footnotetext{
1 Az „alapvető” önbecsülés (angolul „basic”), amit egyes szerzők „globális”-nak jelölnek. A „kiérdemelt” (,elnyert”, angolul „,earning”) önbecsülést és a feltételes (angolul „contingent”) önbecsülést legtöbbször azonos értelemben használják (V. KOMLÓsı, 2007).
} 
Rahinantti és Hannonen, 1997; Koivula, Hassmén és Fallby, 2002). Az önbecsülés interaktív mintázata azt mutatja, hogy a feltételes önbecsülést alkotó versengő (kompetencia) vagy affiliatív (kapcsolati) szükségletek szerepe és következményei az alapönbecsülés mértékétől függnek; a magas alapönbecsüléssel rendelkező személy még mindig tudja növelni az önbecsülését a különböző külső forrásokból merítve, de az önbecsülés csak akkor függ ezektől a forrásoktól és válik maladaptívvá, ha valakinek alacsony az alapönbecsülése (JOHNSON és BLOM, 2007). JOHNSON és FORSMAN (1995) mutatták ki, hogy a kompetenciatörekvések adaptív vagy nem adaptív volta az alapönbecsülés szintjétől függ. Azok a személyek, akik alacsony alapönbecsüléssel rendelkeznek, és erős bennük a törekvés, hogy a kompetencia által önbecsülést érdemeljenek ki, irreálisan erős ambíciót, gyenge teljesítményt és magas fiziológiai reaktivitást mutatnak (FORSMAN és JOHnSON, 1996). Azok az egyének, akiknél mind az alapönbecsülés, mint a kompetenciával kiérdemelt önbecsülés magas, reális ambíciót, jó teljesítményt és alacsonyabb fiziológiai reaktivitást mutatnak. A kompetencián alapuló feltételes önbecsülés szerepet játszik a pszichológiai stresszélményben is. A magas kompetenciaalapú önbecsüléssel rendelkező személyek magasabb vérnyomást, magasabb arousalszintet (irritáltságot, frusztrációt) mutattak feladathelyzetben, mint az alacsony értékkel rendelkezők. A magas kompetenciaalapú önbecsülés olyan kognitív-motivációs struktúra, amely intenzívebb pszichológiai stresszélményhez vezet (Blom, Johnson és PATChing, 2011).

Nem minden alacsony alapönbecsüléssel rendelkező ember keres azonban énmegerősítést sikeres teljesítményeken keresztül. Az alacsony alapönbecsüléssel rendelkező emberek, akikből hiányzik az a szükséglet, hogy a kompetencia által önbecsülést nyerjenek (érdemeljenek ki), elhagyatottnak, függőnek, passzívnak mutatkoznak és az emocionális támogatás magas szükségletével rendelkeznek (JOHNSON és FORSMAN, 1995; JOHNSON, 2002; JOHNSON, 2010).

A JOHNSON és BLOM (2007) által kifejlesztett skála a feltételes önbecsülés két olyan típusát ragadja meg, amelyek az elégtelen alapönbecsülés elméletére épülnek. Az önbecsülés akkor válik feltételessé (függővé) a teljesítmény- vagy affiliatív szükségletektől, ha az alapönbecsülés mértéke alacsony. Az egyén önértékelését növelheti, fenntarthatja saját kompetenciája által (saját belső erőfeszítésein, cselekedeteinek mások általi dicséretén keresztül) vagy kapcsolatain keresztül (a környezet ítélete, a másoktól kapott szeretet által).

\section{A feltételes önbecsülés skála kifejlesztése}

JOHNSON és BLOM (2007) a skálák kialakításánál egy 62 tételből álló készletet vett alapul. Ezeket a tételeket vagy közvetlenül az önbecsülés mérésére létrehozott skálákból válogatták ki a már létező tételeket módosítva, újraszövegezve vagy korábbi empirikus eredményekre és az elméletre alapozva hoztak létre új tételeket.

Azok a tételeket, amelyek ahhoz az attitűdhöz kapcsolódnak, amely szerint a kompetencia és a teljesítményeinkért másoktól kapott visszajelzés a fó meghatározója az egyén önbecsülésének, négy már létező skálából válogatták ki vagy módosí- 
tották: a Depresszív Tapasztalatok Kérdőívből (DEQ) (BLATT, D’AfFLITTI és QUINLAN, 1979) az önkritikára és az introjektált önbecsülésre vonatkozó tételek, négy tétel a Teljesítményalapú önbecsülés skálából (HALLSTEN, JOSEPHSON és TORGÉN, 2005), valamint az Önérték Feltételei mérőeszköz (CROCKER, LUHTANEN, COOPER és BoUvreTte, 2003) és a Kiérdemelt Önbecsülés Skála (ESE, ForSMAN és JOHNSON, 1996) megfelelő tételei. Néhány újonnan létrehozott tétel is volt, azoknak az aspektusoknak a mérésére, mint a tökéletességre való törekvés igénye, az önkritikus attitűd és a kompulzív törekvések.

Azoknak a tételeknek a nagy részét, amelyek az emocionális biztonság és másokkal való közelség fontosságára vonatkoztak, JOHNSON és BLOM (2007) újonnan alkotta meg, tükrözve a szeretetszükségletet, a visszautasítástól való félelmet, a saját szükségletek elnyomását és a konfliktuskerülést. Más tételeket a DEQ-ból (BlatT és mtsai, 1979), illetve a Dependencia skála (Pincus és GurTMan, 1995) elemeiből válogattak ki vagy fogalmaztak újra.

\section{A feltételes önbecsülés skála faktorelemzése}

A kétfaktoros (kapcsolat/kompetenciaalapú) struktúrát feltáró faktoranalízissel tesztelték egy 215, majd 116 fős egyetemista mintán (JOHNSON és BLOM, 2007). A kezdeti 62 tételt főkomponens analízisnek vetették alá, amelynek során 14 egynél nagyobb sajátértékű faktort emeltek ki, amelyek összességében a teljes variancia 68\%-át magyarázták. Ezek közül két, elméleti alapon jól értelmezhető faktort tartottak meg, az első faktor a teljes variancia 30\%-át magyarázta, a második 9\%ot. Ez az első feltáró faktorelemzés alkotta az alapját azon tételek szelekciójának, amelyek a két végső, Kompetenciaalapú és Kapcsolatalapú feltételes önbecsülés skála tételkészletetét képezték. A skálák tételeit négy kritérium alapján válogatták ki: a két kiválasztott faktor közül csak az egyiken súlyozódhattak, legmagasabban az adott faktoron kellett súlyozódniuk (>0,40), kielégítő kommunalitást kellett mutatniuk, és hozzá kellett járulniuk a skálák magas belső konzisztenciájához. E szempontok szerint 27 tétel maradt, ezeket további főkomponens elemzésnek vetették alá. Az első faktor, ahol 13 item (egy itemet eltávolítottak a konfirmátoros faktorelemzés után) vonatkozott a kompetenciára, mint az önbecsülés bázisára, a teljes variancia 33\%-át, a második faktor pedig, amelyen belül 14 tétel vonatkozott a kapcsolati alapú önbecsülésre, a teljes variancia 11\%-át magyarázta.

A feltáró faktorelemzést megerősítő faktorelemzés követte, és az eredmények azt mutatták, hogy a kétfaktoros modell jól illeszkedik az empirikus adatokhoz $(\chi 28=11.16, p=0.19 ;$ RMSEA $=0,04 ;$ NFI $=0,98 ;$ NNFI $=0,99 ;$ CFI $=0,99$; GFI =0,98). A feltáró faktorelemzéssel kapott két új önbecsülés skála faktorstruktúráját külön-külön CFA-val erősítették meg. A Kompetenciaalapú skála 12 tételes két faktoros modellje viszonylag jó illeszkedést mutatott $\left[\chi^{253}=88,05 ; p<0,01\right.$; RMSEA $=0,056$; NFI $=0,96$; NNFI =0,98; CFI =0,98; GFI =0,94]. A Kompetenciaalapú skála két faktora: kompetencián alapuló kontingencia és önkritika. A Kapcsolatalapú önbecsülés 14 tételes három faktoros modellje viszonylag jó illeszkedést mutatott $\left[X^{274}=125,46 ; p<0,001\right.$; RMSEA $=0,057$; (az intervallum alsó határa 0,04 volt); NFI =0,95; NNFI $=0,97$; CFI $=0,98 ; \mathrm{GFI}=0,92]$. A Kap- 
csolatalapú skála három faktora: visszautasítás, szereteten alapuló kontingencia, együttmüködés. A két létrehozott skála korrelált egymással $(r=0,38$, a negatív affektivitás kontrollálása után). A végső összetételű skálákat a szerzők szemantikus differenciál módszerrel is alátámasztották (JOHNSON és BLOM, 2007).

\section{A feltételes önbecsülés reliabilitása és validitása}

JOHNSON és BLOM (2007) 215 különféle szociális helyzetủ személy mintáján tesztelte a feltételes önbecsülés belső konzisztenciáját, amely a Kompetenciaalapú skála esetén 0,89, a Kapcsolat skálánál 0,88 lett. A Kompetenciaalapú skála szignifikánsan és pozitívan korrelált a „toxikus” teljesítményre törekvéssel (STAQ, BiRKs és ROGER, 2000) ( $r=0,41, p<0,001$ szinten), és magasan korrelált az énorientált és szociálisan előírt perfekcionizmussal (MPS, HEWITT és FLETT, 1991) $(r=0,71, p<0,001)$. A Kapcsolatalapú skála szignifikánsan és pozitívan korrelált a függőségi (DEQ, BLATT és mtsai, 1979) $r=0,40 ; p<0,001)$ és affiliációs szükséglettel (IOS, HILL, 1987), $r=0,36 ; p<0,001$ ).

A ROSENBERG-féle (1965) globális önbecsülést mérő skálával mind a kompetencia, mind a kapcsolatalapú önbecsülés szignifikáns negatív kapcsolatot mutatott $(r=-0,40, p<0,001$; illetve $r=-0,38, p<0,001)$, jelezve, hogy mindkét feltételes önbecsülés az alap(vonás) önbecsülés alacsony szintjét tükrözi.

Az optimizmus-pesszimizmus skálával (LOT, SCHEIER és CARvER, 1985) szintén negatív kapcsolatot mutattak az alskálák $(r=-0,13$, illetve $r=-0,19 ; p<0,001)$. A negatív affektivitás (PANAS; WATSON, ClARK és TELLEGEN, 1988) szignifikáns, közepes erősségủ együttjárást mutatott mindkét alskálával $(r=0,45$, illetve $r=0,52$; $p<0,001)$.

A Kompetenciaalapú skála és függőség/affiliáció skálák, valamint a Kapcsolatalapú skála és teljesítmény skálák között nullához közeli korrelációt mértek, amely a skálák jó diszkrimináns validitását mutatja. A teszt-reteszt reliabilitást 50 fővel öthetes intervallumban végezték, s meglehetősen magasnak adódott: a Kompetenciaalapú skála esetében $r=0,93$, a Kapcsolatalapú esetében pedig $r=0,80$.

\section{Nemi különbségek}

Az egyszempontos ANOVA-k megmutatták (N=331), hogy a nők mind a Kompetencia-, mind a Kapcsolatalapú önbecsülés skálán szignifikánsan magasabb átlagpontszámot értek el, mint a férfiak: $M=2,99$ vs. $M=2,75$, illetve $M=3,09$ vs. $\mathrm{M}=2,87$. Ezek az eredmények arra utalhatnak, hogy a nők önbecsülése mind a kapcsolati megerősítéshez, mind a jó teljesítményhez erősebben kötődik, mint a férfiaké.

\section{Vizsgálatunk célja}

Jelen vizsgálat célja a Feltételes Önbecsülés Skála magyar verziójának elkészítése, pszichometriai vizsgálata, valamint kérdőíves validálása volt. 
272 fő egyetemi hallgató alkotta a mintát, 75 férfi és 197 nő, a résztvevők átlagos életkora 23,48 év (19-30 év, SD=2,144) volt. A 2. adatfelvétel során 153 fö́t sikerült elérnünk $(56,2 \%)$. A részvétel névtelen és önkéntes volt, a kérdőívek kitöltésére egyetemi előadások végén került sor.

\section{Méröeszközök}

A 26 tételes Feltételes Önbecsülés Skála ${ }^{2}$ (CSES, Contingent Self-Esteem Scale; JOHNSON és BLOM, 2007) négyfokú Likert-skálán méri az egyén feltételes önbecsülésének szintjét két dimenzió mentén. A Kompetenciaalapú önbecsülés (CSES-C) a kompetencián, a saját belső erőfeszítésen alapuló önbecsülést méri: például „Néha az eredményeimmel próbálom bizonyítani, hogy értékes vagyok”. A Kapcsolatalapú önbecsülés (CSES-R) mások visszatükrözéséből, szeretetéből „táplálkozó” önbecsülést méri: például „Az önbecsülésem könnyen ingadozik annak függvényében, hogy az elfogadás vagy elutasitás jelzéseit kapom-e másoktól." Az eredeti kérdőívet V. Komlósi és Kökönyei fordították magyarra Johnson engedélyével, majd magyarról angolra történő visszafordítást is alkalmaztak (V. Komlósi, személyes közlés). Egyetemista mintán a következő reliabilitásadatokat kapták: a Kompetenciaalapú önbecsülés Cronbach-alfa értéke 0,81, a Kapcsolatalapú önbecsülés Cronbach-alfa értéke pedig 0,86 lett.

Az Önmagunk iránt érzett együttérzés, röviden Önegyüttérzés skála (Self-Compassion Scale, SCS; NefF, 2003; magyar változat SÁGI, KöTELES és V. KOMLÓsI, 2013, SCS-H) esetében ötfokú Likert-skálán (szinte soha-majdnem mindig) kell megítélni 26 állítást, amelyek három alskálát alkotnak: 1. Önmagunk iránt érzett kedvesség vs. Önbírálat 2. Közös emberi természet vs. Izoláció, 3. Jelentudatosság vs. Túlzott azonosulás; a skála belső reliabilitása 0,86 volt (SÁGI, KÖTELES és V. KOMLÓsI, 2013).

A Rosenberg-féle Önbecsülés Skála (Rosenberg Self-Esteem Scale, RSES; ROSENBERG, 1965) világszerte nagyon gyakran használt, 10 tételes kérdőív. A globális önbecsülést négyfokú Likert-skálán méri, a tételek az önelfogadásra és önmagunk észlelt értékességére vonatkoznak. A kérdőívnek több magyar fordítása is ismert, jelen vizsgálatban a Kiss Paszkál (2009) által jegyzett verziót használtuk, ami korábban más vizsgálatokban is jó pszichometriai jellemzőkkel bírt (BÉRDI és KÖTELES, 2010), ennek belső konzisztenciája 0,82 volt.

Az általános szorongási szint mérésére a Spielberger-féle Állapot- és Vonásszorongás Kérdő́v (STAI; State-Trait Anxiety Inventory; SPIElberger, GORSUCH és Lushene, 1970) magyar változatának (Sipos K., Sipos M. és SPielberger, 1994) vonásszorongást mérő 20 tételét (STAI-T) használtuk. A kérdőív a szorongással kapcsolatba hozható testi és pszichés állapotokat értékelteti 4-pontos Likert-ská-

${ }^{2}$ A teljes kérdőívet lásd a Függelékben. 
lán. Belső reliabilitása rendszerint magas, 0,9 körüli (STAUDER és KONKOLŸ THEGE, 2006; Köteles, Szemerszky, Freyler és BÁrdos, 2011; Freyler, KŐhegyi, KÖTELES, KÖKÖNYEI és BÁRDOS, 2013).

A Beck-féle Depresszió Kérdöí (BDI, Beck Depression Inventory, BECK, WARD, Mendelsohn, Mock és ERBAUGH, 1961) lehetővé teszi a depresszió súlyosságának megítélését érzelmi, kognitív, motivációs és szomatikus területeken 21 tétel segítségével, reliabilitása 0,81 nem klinikai mintán (BECK, STEER és CARBIN, 1988). Az értékelésnél a megállapítások előtt szereplő számot, illetve ha egy tételnél a személy több számot is megjelölt, akkor a nagyobb számot vesszük figyelembe. Az így kapott számokat összeadjuk (KOPP és FóRIS, 1995).

A diszpozicionális optimizmus mérésére a 10 tételes, ötfokú Likert-skálán mérő Életszemlélet Tesztet (LOT, Life Orientation Test Revisited; SCHEIER, CARver és BRIDGES, 1994; magyar változat: BÉRDI és KÖTELES, 2010) használtuk. A mérőeszköz 4 „töltelék” tételt $(2 ., 5,6,8)$ tartalmaz, amelyeket nem számolunk bele az értékelésbe. A teljes pontszámot alkotó 6 tétel közül 3 pozitív (1., 4. és 10. tétel), 3 pedig negatív irányú (3., 7. és 9. tétel). A magyar verzió reliabilitása a legtöbb korábbi vizsgálatban 0,7-0,8 körül alakult (KÖTELES és BÁRDOS, 2011; KÖTELES és FERENTZI, 2012).

\section{EREDMÉNYEK}

A felvett változók leíró statisztikai adatait és a skálák normalitásvizsgálatát az 1. táblázat foglalja össze.

1. táblázat. A vizsgált változók átlaga, szórása, tapasztalati minimum- és maximumértékei, valamint a normalitást vizsgáló Kolmogorov-Szmirnov-statisztika eredményei $(\mathrm{N}=272)$

\begin{tabular}{|l|c|c|c|}
\hline \multicolumn{1}{|c|}{ V ál t o z ó } & $\mathrm{M} \pm \mathrm{SD}$ & $\min -\max$ & $\begin{array}{c}\text { Kolmogorov- } \\
\text { Szmirnov Z }\end{array}$ \\
\hline életkor & $23,48 \pm 2,14$ & $19-30$ & $2,8^{* * *}$ \\
\hline CSES feltételes önbecsülés & $65,19 \pm 11,48$ & $35-96$ & 0,88 \\
\hline CSES-C kompetencia skála & $27,91 \pm 5,98$ & $13-47$ & 0,93 \\
\hline kompetencia & $18,64 \pm 4,03$ & $9-31$ & 1 \\
\hline önkritika & $9,27 \pm 2,58$ & $4-16$ & $1,6^{* *}$ \\
\hline CSES-R kapcsolati skála & $37,33 \pm 7,02$ & $19-55$ & 0,80 \\
\hline visszautasítás & $15,02 \pm 3,06$ & $7-24$ & 1,23 \\
\hline szeretet & $12,83 \pm 2,19$ & $5-16$ & $1,76^{* *}$ \\
\hline együttmüködés & $9,51 \pm 2,79$ & $4-16$ & $1,82^{* *}$ \\
\hline SCS-H önegyüttérzés & $90,17 \pm 12,6$ & $41-124$ & 0,99 \\
\hline RSES globális önbecsülés & $31,89 \pm 5,21$ & $13-40$ & $1,57^{*}$ \\
\hline STAI-T vonásszorongás & $42,9 \pm 9,5$ & $22-72$ & 0,66 \\
\hline BECK depresszió & $8,35 \pm 7,64$ & $0-61$ & $2,53^{* * *}$ \\
\hline LOT-R optimizmus & $22,47 \pm 4,55$ & $6-30$ & $1,55^{*}$ \\
\hline
\end{tabular}

Megjegyzés: *: $p<0,05 ;{ }^{* *}: p<0,01 ;{ }^{* * *}: p<0,001$ 
A vizsgálatban használt kérdőíveket reliabilitás vizsgálatnak vetettük alá, az eredmények a 2. táblázatban láthatóak.

2. táblázat. A felvett változók reliabilitását vizsgáló Cronbach-alfa értékek a vizsgált két időpontban

\begin{tabular}{|c|c|c|c|}
\hline \multicolumn{1}{|c|}{ Skála neve } & $\begin{array}{c}\text { Cronbach-alfa 1. } \\
\mathrm{N}=272\end{array}$ & $\begin{array}{c}\text { Cronbach-alfa 2. } \\
\mathrm{N}=153\end{array}$ & Tételszám \\
\hline SCS-H önegyüttérzés & 0,84 & 0,91 & 26 \\
\hline RSES globális önbecsülés & 0,89 & 0,8 & 10 \\
\hline CSES feltételes önbecsülés & 0,89 & 0,9 & 26 \\
\hline CSES-C kompetencia skála & 0,83 & 0,86 & 12 \\
\hline kompetencia & 0,76 & 0,78 & 8 \\
\hline önkritika & 0,73 & 0,79 & 4 \\
\hline CSES-R kapcsolati skála & 0,86 & 0,87 & 14 \\
\hline visszautasítás & 0,76 & 0,81 & 6 \\
\hline szeretet & 0,73 & 0,73 & 4 \\
\hline együttműködés & 0,8 & 0,79 & 4 \\
\hline STAI-T vonásszorongás & 0,9 & & 20 \\
\hline LOT-R optimizmus & 0,82 & & 6 \\
\hline
\end{tabular}

A feltételes önbecsülés skálák időbeli stabilitását (egy hónap különbséggel) Pearson-féle korrelációkkal mértük, a teljes skálára nézve $r=0,79$; a Kompetenciaalapú skála $r=0,77$; a Kapcsolatalapú skála pedig $r=0,74(p<0,001)$ lett.

A nemi különbségek vizsgálatára $t$-próbát végeztünk, nem kaptunk szignifikáns különbséget: $t=-0,327, \mathrm{df}=270 ; p=0,74$. Az életkorral nem korrelált a feltételes önbecsülés $r=-0,009 ; p=0,88$.

A feltételes önbecsülés konvergens validitását Pearson-korrelációkkal mértük (lásd 3. táblázat). A Feltételes önbecsülés és skálái is, a Kompetencia- és a Kapcsolati alapú önbecsülés, az önegyüttérzéssel és a globális önbecsüléssel közepesen erős

3. táblázat. A Feltételes Önbecsülés Skála konvergens validitását vizsgáló Pearson-korrelációk eredményei $(\mathrm{N}=272)$

\begin{tabular}{|l|c|c|c|}
\hline \multicolumn{1}{|c|}{ Skála neve } & CSES & $\begin{array}{c}\text { CSES-C } \\
\text { kompetencia }\end{array}$ & $\begin{array}{c}\text { CSES-C } \\
\text { kapcsolat }\end{array}$ \\
\hline SCS-H önegyüttérzés & $-0,52^{* * *}$ & $-0,45^{* *}$ & $-0,47^{* *}$ \\
\hline RSES globális önbecsülés & $-0,59^{* *}$ & $-0,48^{* *}$ & $-0,56^{* *}$ \\
\hline STAI-T vonásszorongás & $0,66^{* *}$ & $0,53^{* *}$ & $0,62^{* *}$ \\
\hline BECK depresszió & $0,43^{* *}$ & $0,34^{* *}$ & $0,42^{* *}$ \\
\hline LOT-R optimizmus & $-0,38^{* * *}$ & $-0,39^{* *}$ & $-0,29^{* *}$ \\
\hline
\end{tabular}

Megjegyzés: ${ }^{* *}: p<0,01$ 
negatív, míg az optimizmussal mérsékelt negatív kapcsolatot mutatott. A vonásszorongással és a depresszióval mindhárom Feltételes Önbecsülés Skála együttjárása közepesen erős és pozitív irányú volt.

\section{DISZKUSSZIÓ}

A Feltételes Önbecsülés Skála magyar változatával végzett első vizsgálat azt mutatja, hogy a skála pszichometriai jellemzői jók, megfelelő reliabilitás adatokkal bír és az eredeti változathoz hasonló validitás eredményeket kaptunk: az önegyüttérzéssel, a globális önbecsüléssel és az optimizmussal negatív, míg a vonásszorongással és a depresszióval pozitív kapcsolatot mutatott a feltételes önbecsülés.

\section{VIZSGÁLAT}

A 2. vizsgálat célja az volt, hogy más vizsgálati mintákon is megvizsgáljuk a feltételes önbecsülés kérdőív pszichometriai jellemzőit, illetve hogy új validáló kérdőíveket is alkalmazzunk, úgymint szubjektív jóllét és pozitív, negatív affektivitás. Továbbá célunk volt megvizsgálni, hogy van-e különbség a különböző minták (egyetemista, táncos és aerobikozó) között a feltételes önbecsülés tekintetében. A három minta az adatgyűjtés forrása miatt különböző kompetencia területekhez (tudományos teljesítmény, koordinációs és fizikai teljesítmény) kapcsolódik. A tánc és az aerobik abban is különbözik, hogy előbbi inkább művészi, utóbbi pedig sportteljesítmény.

\section{MÓDSZER}

\section{Vizsgálati személyek}

Rendszeresen táncoló 162 fő (52 férfi és 110 nő) alkotta az 1. vizsgálati mintát. A résztvevők átlagos életkora 28,5 év volt (18-58 évesek, $\mathrm{SD}=8,59)$. A heti táncóra átlaga 2,54 volt, a tánc elkezdése óta eltelt idő átlaga 42,56 hónap volt. A résztvevőket részben személyesen, papír-ceruza teszttel, részben online értük el.

A 2. mintát 208 rendszeresen aerobikozó nő alkotta, átlagos életkor 28,4 év $\left(18-60\right.$ év $\left.^{3}, \mathrm{SD}=8,46\right)$ volt. A résztvevők átlagosan 49,8 hónapja $(1-420 ; \mathrm{SD}=$ $73,34)$ edzettek, a minta 50,5\%-a (105 fó) kevesebb, mint 1 éve, 49,5\% -a (103 fó) pedig több mint 1 éve edzett. A vizsgálati személyek átlagosan heti 3,1 alkalommal $(1-19 ; \mathrm{SD}=2,77)$ aerobikoztak vagy zumbáztak. Kényelmi mintavételt alkalmaztunk, az adatgyűjtést aerobik-edzéseket tartó budapesti klubokban, részben az interneten keresztül, részben személyesen végeztük. ${ }^{4} \mathrm{~A}$ három különböző minta

3 18-25 év között 96 fo, 25-40 év között 89 fő, 40-60 év között 23 fő.

4 A minta részben átfed SÁGI, SzEKERES és KÖTELES (2012) tanulmányában használt mintával. 
(egyetemista,táncos, aerobikozó) különböző forrásokból származott, nincs átfedés a résztvevők között. Az egyetemisták körében nem kérdeztünk rá arra, hogy ki táncol, esetleg aerobikozik.

\section{Méröeszközök}

A Rosenberg-féle Önbecsülés Skála (RSES, ROSENBERG, 1965) (reliabilitása táncos minta 0,9; aerobikos minta 0,88), valamint a 26 tételes Feltételes Önbecsülés Skála (CSES, JOHNSON és BLOM, 2007) (reliabilitása mindkét mintán 0,74 és 0,85 között volt).

A WHO Jóllét Kérdőŕv rövidített változata (WHO-Five Well-being Index, WBI-5) (BeCH, StaeHr-Johansen és Gudex, 1996) a kitöltők általános közérzetéről ad információt az elmúlt kéthetes időszak vonatkozásában. A teszt négyfokú Likertskálákon mér, fordított tételt nem tartalmaz. A magyar verziót Susánszky és munkatársai validálták (SuSÁNSZKY, KONKOLŸ THEGE, STAUDER és KOPP, 2006), belső konzisztenciája korábbi vizsgálatok alapján 0,69 és 0,85 között alakult (KÖTELES és SIMOR, 2014b), jelen mintákon 0,72 és 0,77 .

A Rörviditett Pozitív és Negatíu Affektivitás Skála (Positive and Negative Affectivity Schedule - PANAS) az eredeti (WATSON és mtsai, 1988) 20 tételes, a pozitív és negatív érzelmi állapotok mérésére kidolgozott kérdőív rövidített verziója. A mérőeszköz 5-5 pozitív (például aktív, elszánt), illetve negatív (például ellenséges, ideges) érzelmi állapotot sorol fel, amit ötpontos Likert-skálán kell értékelni. A két alskála többé-kevésbé függetlennek tekinthető egymástól. A magyar verzió nem tért el lényegesen az eredeti, hosszabb változattól, és elfogadható belső konzisztenciával (0,65 fölött a negatív, 0,7 fölött a pozitív affektivitás) bír (GYOLLAI, SimOR, KÖteles és Demetrovics, 2011; KÖTELES és SimOR, 2013, 2014a). Jelen vizsgálatban a táncos mintán a pozitív affektivitás reliabilitása 0,74 , a negatívé pedig 0,70 , aerobikos mintán a pozitív 0,36 , míg a negatív affektivitás 0,70 lett. A pozitív affektivitást így a további elemzésekből kihagytuk az aerobikos mintán.

\section{EREDMÉNYEK}

\section{Táncos minta}

A skálák normál eloszlását vizsgáló Kolmogorov-Szmirnov-próba egyik esetben sem volt szignifikáns, így nem paraméteres korrelációs vizsgálatokat (lásd 4. táblázat) végeztünk a Feltételes Önbecsülés Skála validitásának vizsgálatára. 
4. táblázat. A feltételes önbecsülés skálák konvergens validitását vizsgáló Kendall-féle tau-b együtthatók ( $N=162)$

\begin{tabular}{|l|c|c|c|}
\hline \multicolumn{1}{|c|}{ Skála neve } & CSES & $\begin{array}{c}\text { CSES-C } \\
\text { kompetencia }\end{array}$ & $\begin{array}{c}\text { CSES-R } \\
\text { kapcsolati }\end{array}$ \\
\hline RSES globális önbecsülés & $-0,41^{* *}$ & $-0,54^{* *}$ & $-0,53^{* *}$ \\
\hline WBI-5 jóllét & $-0,23^{* *}$ & $-0,32^{* *}$ & $-0,28$ \\
\hline PANAS+ pozitív affektivitás & $-0,14^{*}$ & $-0,14$ & $-0,29^{* *}$ \\
\hline PANAS- negatív affektivitás & $0,42^{* *}$ & $0,52^{* *}$ & $0,52^{* *}$ \\
\hline
\end{tabular}

Megjegyzés: *: $p<0,05 ;{ }^{* *}: p<0,01$

\section{DISZKUSSZIÓ}

A Feltételes Önbecsülés Skála a táncosok mintáján is jó reliabilitás értékeket mutatott, valamint az újabb kérdőívekkel történő validitása is megfelelőnek bizonyult. Mindhárom feltételes önbecsülés skála szignifikánsan negatívan korrelált a globális önbecsüléssel, a jólléttel és a pozitív affektivitással, valamint szignifikánsan pozitívan korrelált a negatív affektivitással.

\section{EREDMÉNYEK}

\section{Aerobikos minta}

Ellenőriztük a változók normalitását és mivel az sok esetben sérült, nem paraméteres méréseket végeztünk a konvergens validitás ellenőrzésére (lásd 5. táblázat).

5. táblázat. A nem-paraméteres korrelációs vizsgálat eredményei (Kendall-féle tau-b együtthatók, $\mathrm{N}=208$ )

\begin{tabular}{|l|c|c|c|}
\hline \multicolumn{1}{|c|}{ Skála neve } & CSES & $\begin{array}{c}\text { CSES-C } \\
\text { kompetencia }\end{array}$ & $\begin{array}{c}\text { CSES-R } \\
\text { kapcsolati }\end{array}$ \\
\hline RSES globális önbecsülés & $-0,39^{* *}$ & $-0,3^{* * *}$ & $-0,36^{* * *}$ \\
\hline WBI-5 jóllét & $-0,19^{* *}$ & $-0,19^{* * *}$ & $-0,15^{* *}$ \\
\hline PANAS- negatív affektivitás & $0,37^{* *}$ & $0,35^{* * *}$ & $0,33^{* * *}$ \\
\hline
\end{tabular}

Megjegyzés: ${ }^{* *}: p<0,01 ;{ }^{* * *}: p<0,001$

\section{Megerösítö faktorelemzés}

A kérdőív faktorstruktúrájának ellenőrzése az IBM Amos programjának 21.0-es verziójával történt. A megerősítő faktorelemzés során a három mintát egyszerre vizsgáltuk maximum likelihood módszerrel. A két skála (kompetenciaalapú, illetve kapcsolatalapú feltételes önbecsülés) közötti korrelációt (a háttérben álló elmélettel összhangban) megengedtük. 
A megerősítő faktorelemzés során az elméleti modellhez való illeszkedés mértékét jellemző mutatók közül a szabadságfokok számát is figyelembe vevő CMIN/ df 2,183-as értéke $(\mathrm{CMIN}=1919,088, \mathrm{df}=879, p<0,001)$, illetve az RMSEA 0,042es $(0,039-0,044)$ értéke meglehetősen jó illeszkedésre utalnak, miközben az alapszint-összehasonlításon alapuló indexek jóval gyengébbek ( $\mathrm{IFI}=0,835$; $\mathrm{CFI}=0,831$ ). Ennek alapján az illeszkedést összességében elfogadható mértékűnek mondhatjuk.

A három vizsgálati minta összehasonlítására többszempontos varianciaanalízist (ANOVA) végeztünk. A Feltételes Önbecsülés Skálán elért összpontszám $(\mathrm{df}=634$, $f=2,25, p=0,106$ ) és Kompetenciaalapú skála tekintetében nem volt szignifikáns különbség a csoportok között $\mathrm{df}=638, f=0,387 p=0,67$. A Kapcsolat skála mentén azonban szignifikáns különbség volt a csoportok között $\mathrm{df}=638, f=6,997, p<0,001$ (egyetemista minta $\mathrm{M}=37,3$ aerobikos és táncos minta $\mathrm{M}=35,2$ ).

\section{DISZKUSSZIÓ}

A tanulmány a Feltételes Önbecsülés Skála magyar változatának több mintán történő (egyetemista, táncos, aerobikozó) validálását tủzte ki célul és a következő eredményeket kaptuk.

Az 1. vizsgálatban egyetemisták mintáján két alkalommal, egy hónapos különbséggel végeztünk adatgyűjtést. Mind az első, mind a második tesztfelvétel során a Feltételes Önbecsülés Skála és két fő skálája (Kompetenciaalapú és Kapcsolatalapú feltételes önbecsülés) belső konzisztenciaértéke magas, 0,72 és 0,906 közötti volt, ami a skála megbízhatóságát jelzi. A teszt-reteszt vizsgálat során igazolódott a feltételes önbecsülés idői stabilitása, bár valamivel alacsonyabb értékeket kaptunk az eredeti változathoz képest. A két másik mintán (táncos, aerobikozó) is megfelelő volt csaknem minden reliabilitásérték, egyedül az aerobikos mintán mért önkritika alskála 0,62-es értéke nem fogadható el. Életkori, és nemi különbséget sem mutatott a feltételes önbecsülés szemben JOHNSON és BLOM (2007) eredményeivel.

A skála globális önbecsüléssel való kapcsolata megegyezik a szakirodalomban kapott korábbi eredményekkel, miszerint a globális önbecsüléssel (JOHNSON és BLOM, 2007) és az önegyüttérzéssel negatívan (NEFF és VONK, 2009; NEFF, 2011) jár együtt. A Feltételes Önbecsülés Skála negatívan kapcsolódott a mentális egészséget jelző pszichológiai jellemzőkhöz, úgymint jóllét, pozitív affektivitás és optimizmus, valamint pozitív kapcsolatot mutatott a depresszióval, a vonásszorongással és a negatív affektivitással, hasonlóan az eredeti változattal kapott eredményekhez (JOHnson és BLOM, 2007; Crocker és PARK, 2004).

A három vizsgálati minta összevetése azt mutatta, hogy az egyetemisták magasabb Kapcsolati alapú önbecsüléssel rendelkeznek, mint a táncosok és az aerobikozók, tehát számukra fontosabbak a társkapcsolataik az önbecsülésük szempontjából, mint a két másik csoportnak. Bár a három minta különböző területekhez kapcsolódott, az eredmények sokban hasonlítanak, ami jó külső validitást jelez.

A faktorszerkezetet vizsgáló megerősítő faktorelemzés azt mutatta, hogy a magyar Feltételes Önbecsülés Skála faktorszerkezete még megfelelő, bár az eredeti kérdőívnél is kissé alacsonyabb illeszkedési mutatókat kaptunk. 


\title{
KÖVETKEZTETÉSEK
}

A Feltételes Önbecsülés Skála magyar változatának első vizsgálata azt mutatja, hogy a 26 tételes skála összességében pszichometriailag (belső konzisztencia, faktorstruktúra) megfelelőnek tűnik. Szükség volna további vizsgálatokra, valamint más pszichológiai jellemzőket, úgymint élettel való elégedettség, boldogság, perfekcionizmus is mérni, illetve a továbbiakban megvizsgálnánk az alap- és feltételes önbecsülés különböző kombinációinak kapcsolatát más pszichometriai jellemzőkkel.

A kétféle önbecsülési attitűd, a kompetenciára, illetve a kapcsolatokra épülő, a szükségletek és félelmek különböző fajtáit váltja ki a stresszel és kihívással való szembesülés esetén (JOHNSON és BLOM, 2007). Az alacsony alap- és magas kompetenciaalapú önbecsülés kombináció erősen köthető olyan stresszel összefüggő szindrómákhoz, mint például a kimerülésből fakadó depresszió (DUNKLEY, ZUROFF és BLANKSTEIN, 2003; JOHNSON, 2002) és a kiégés folyamata (HALLSTEN és mtsai, 2005). Ezzel szemben a kapcsolatalapú önbecsülés fogalmi szerkezete arra az én-attitűdre vonatkozik, amely fogékonnyá tesz az interperszonális közeledések maladaptív mintázatára. Az a meggyőződés, hogy valakinek az önértéke a másoktól jövő emocionális megerősítésektől függ, egy túlzott együttműködést és konformitást hoz létre a másokkal való viselkedésben a visszautasítás és a nemtetszés elkerülése érdekében (JOINER és METALSKY, 2001). Ez a konformitás gyakran a saját érzések és szükségletek elnyomásával jár (PINCUS és WILSON, 2001). Paszszívnak, szorongónak és gátoltnak lenni, az emberek ezzel a feltételes (feltételes) önbecsüléssel hajlamosak érzelmi coping stratégiákat használni és érzékenynek lenni a kapcsolati feszültségre (Gillath, Bunge, Shaver, Wendelken és MikUlincer, 2005; GUdJONSSON és SiguRdSSON, 2003); másokhoz kötődni fontos, de ugyanakkor az énnel kapcsolatos veszélyek forrása.

A feltételes önbecsülés skálák értékes eszközt adnak ahhoz, hogy megértsük a különböző sérülékenységi mintázatok hátterét, amelyek kapcsolatban állnak a stresszel, a megküzdéssel és az egészséggel, valamint jól használhatóak az önbecsülés-kutatásokban, és az önbecsülés fejlesztését szolgáló tréningek, terápiák hatásának mérésére, nyomon követésére.

\section{FÜGGELÉK}

\section{A Feltételes Önbecsülés Skála magyar változata (CSES-H)}

Kérjük, 4 fokú skálán ítélje meg az alábbi állításokat, hogy mennyire jellemzőek Önre.

\author{
1 - Egyáltalán nem jellemző rám \\ 2 - Nem jellemző rám \\ 3 - Jellemző rám \\ 4 - Erősen jellemző rám
}




\begin{tabular}{|c|c|c|c|c|}
\hline $\begin{array}{l}\text { 1. Ha megbukom egy vizsgán, vagy ha egy helyzetben rosszabbul tel- } \\
\text { jesítek, mint azt elvártam, kételkedni kezdek, hogy valóban értékes } \\
\text { vagyok-e. }\end{array}$ & 1 & 2 & 3 & 4 \\
\hline $\begin{array}{l}\text { 2. Határozottan növekszik az önbecsülésem, ha mások keresik a tár- } \\
\text { saságomat. }\end{array}$ & 1 & 2 & 3 & 4 \\
\hline $\begin{array}{l}\text { 3. Ha konfliktusaim vagy vitáim vannak a párommal vagy a közeli ba- } \\
\text { rátaimmal, tehetetlennek érzem magam, és kudarcként élem meg. }\end{array}$ & 1 & 2 & 3 & 4 \\
\hline $\begin{array}{l}\text { 4. Nem számít, hogy mennyire jól végeztem el egy feladatot, mert } \\
\text { mindig az a gyötrő érzés van bennem, hogy még jobban kellett } \\
\text { volna csinálnom. }\end{array}$ & 1 & 2 & 3 & 4 \\
\hline 5. Mások sikerét fenyegetőnek érzem. & 1 & 2 & 3 & 4 \\
\hline $\begin{array}{l}\text { 6. Úgy érzem, a szoros kapcsolataimban a szeretetet és elfogadást ki } \\
\text { kell érdemelnem. }\end{array}$ & 1 & 2 & 3 & 4 \\
\hline $\begin{array}{l}\text { 7. Fontos számomra, hogy a páromtól gyakran bizonyságot kapjak } \\
\text { arról, hogy szeret. }\end{array}$ & 1 & 2 & 3 & 4 \\
\hline $\begin{array}{l}\text { 8. Úgy érzem, nem számít, mennyire keményen dolgozom, soha nem } \\
\text { érem el, hogy a legjobb teljesítményt nyújtsam. }\end{array}$ & 1 & 2 & 3 & 4 \\
\hline $\begin{array}{l}\text { 9. Néha az eredményeimmel próbálom bizonyítani, hogy értékes } \\
\text { vagyok. }\end{array}$ & 1 & 2 & 3 & 4 \\
\hline $\begin{array}{l}\text { 10. Amikor egy szerelmi kapcsolatom véget ér, igazán hasznavehetet- } \\
\text { lennek és értéktelennek érzem magam. }\end{array}$ & 1 & 2 & 3 & 4 \\
\hline $\begin{array}{l}\text { 11. Úgy gondolom, az határozza meg, hogy mennyire vagyok értékes } \\
\text { személy, hogy mennyire tudom a dolgaimat sikerre vinni. }\end{array}$ & 1 & 2 & 3 & 4 \\
\hline $\begin{array}{l}\text { 12. Könnyen nyugtalanná válok, amikor éppen nincs semmi megolda- } \\
\text { ni való dolgom. }\end{array}$ & 1 & 2 & 3 & 4 \\
\hline $\begin{array}{l}\text { 13. Hajlamos vagyok elnyomni az érzéseimet és a szükségleteimet } \\
\text { azért, hogy mások jól érezzék magukat. }\end{array}$ & 1 & 2 & 3 & 4 \\
\hline 14. Az önbecsülésemhez fontos, hogy szeressenek. & 1 & 2 & 3 & 4 \\
\hline $\begin{array}{l}\text { 15. Nem az számít, hogy „ki vagyok én”, hanem hogy „mit tudok vég- } \\
\text { hez vinni”. }\end{array}$ & 1 & 2 & 3 & 4 \\
\hline $\begin{array}{l}\text { 16. Hajlamos vagyok rá, hogy önalávető legyek, vagy elfogadjam má- } \\
\text { sok akaratát, nehogy elveszítsem az elfogadásukat és a kitüntető } \\
\text { figyelmüket. }\end{array}$ & 1 & 2 & 3 & 4 \\
\hline 17. Az önbecsülésem erőteljesen függ a napi teljesítményeimtől. & 1 & 2 & 3 & 4 \\
\hline $\begin{array}{l}\text { 18. Hajlamos vagyok rá, hogy túlságosan is tekintettel legyek mások } \\
\text { érzéseire a saját érzéseim és szükségleteim kárára. }\end{array}$ & 1 & 2 & 3 & 4 \\
\hline
\end{tabular}




\begin{tabular}{|c|c|c|c|c|}
\hline $\begin{array}{l}\text { 19. Az önbecsülésem könnyen ingadozik annak függvényében, hogy az } \\
\text { elfogadás vagy elutasítás jelzéseit kapom-e másoktól. }\end{array}$ & 1 & 2 & 3 & 4 \\
\hline 20. Mások sikerei arra ösztönöznek, hogy még keményebben dolgozzak. & 1 & 2 & 3 & 4 \\
\hline $\begin{array}{l}\text { 21. Mások szeretetére és támogatására is szükségem van ahhoz, hogy } \\
\text { jobban szeressem magam. }\end{array}$ & 1 & 2 & 3 & 4 \\
\hline $\begin{array}{l}\text { 22. Előfordul, hogy megengedem, hogy rosszul bánjanak velem, mert } \\
\text { nem akarom megkockáztatni, hogy elutasítsanak. }\end{array}$ & 1 & 2 & 3 & 4 \\
\hline 23. Csak olyankor érzem magam értékes embernek, ha jól teljesítettem. & 1 & 2 & 3 & 4 \\
\hline $\begin{array}{l}\text { 24. Ha egy szerelmi kapcsolatban visszautasítanak, értéktelennek ér- } \\
\text { zem magam. }\end{array}$ & 1 & 2 & 3 & 4 \\
\hline $\begin{array}{l}\text { 25. Érzékenyen érint, ha másoktól az ellenszenv és elutasítás jelei ér- } \\
\text { keznek felém. }\end{array}$ & 1 & 2 & 3 & 4 \\
\hline $\begin{array}{l}\text { 26. Nehezen bocsátom meg magamnak, ha kudarcot vallok egy fontos } \\
\text { feladatban. }\end{array}$ & 1 & 2 & 3 & 4 \\
\hline
\end{tabular}

Kompetenciaalapú önbecsülés: $\quad$ 1., 4., 5., 8., 9., 11., 12., 15., 17., 20., 23., 26.

Kapcsolatalapú önbecsülés: $\quad$ 2., 3., 6., 7., 10., 13., 14., 16., 18., 19., 21., 22., 24., 25.

\section{IRODALOM}

Bech, P., Staehr-Johansen, K., \& Gudex, C. (1996). The WHO (Ten) Well-Being Index: Validation in diabetes. Psychotherapy and Psychosomatics, 65(4), 183-190.

Beck, A. T., Steer, R. A., \& Carbin, M. G. (1988). Psychometric properties of the Beck Depression Inventory: Twenty-five years of evaluation. Clinical Psychology Review, 8(1), $77-100$.

Beck, A. T., Ward, C. H., Mendelsohn, M., Mock, J., \& Erbaugh, J. (1961). An inventory for measuring depression. Archives of General Psychiatry, 4, 561-571.

BÉRDi M. és KÖTELES F. (2010). Az optimizmus mérése: az Életszemlélet Teszt átdolgozott változatának (LOT-R) pszichometriai jellemzői hazai mintán. Magyar Pszichológiai Szemle, 65(2), 273-294.

Birks, Y., \& Roger, D. (2000). Identifying components of type A behaviour: "Toxic" and "non-toxic" achieving. Personality and Individual Differences, 28, 1093-1105.

Blatt, S. J., D’Afflitti, J. P., \& Quinlan, D. M. (1979). The Depressive Experiences Questionnaire. Unpublished manuscript, Yale University, New Haven, CT.

Blom, V., Johnson, M., \& Patching, G. F. (2011). Physiological and behavioral reactivity when one's self- worth is staked on competence Individual Differences Research, 9(3), $138-152$.

Bowlby, J. (1980). Attachment and loss, Vol. 3. Loss separation and depression. New York: Basic Books. 
Crocker, J. (2002). The costs of seeking self-esteem. Journal of Social Issues, 58(3), 597-615.

Crocker, J. (2006). Having vs. pursuing self-esteem: Costs and benefits. In M. H. Kernis (Ed.), Self-Esteem: Issues and answers (274-280). New York: Psychology Press.

Crocker, J., Luhtanen, R., Cooper, M. L., \& Bouvrette, S. A. (2003). Contingencies of self-worthin college students: Measurement and theory. Journal of Personality and Social Psychology, 85(5), 894-908.

Crocker, J., \& Park, L. E. (2004). The costly pursuit of self-esteem. Psychological Bulletin, 130(3), 392-414.

Crocker, J., \& Wolfe, C. T. (2001). Contingencies of self-worth. Psychological Review, 108(3), 593-623.

Dunkley, D. M., Zuroff, D. C., \& Blankstein, K. R. (2003). Self-critical perfectionism and daily affect: Dispositional and situational influences on stress and coping. Journal of Personality and Social Psychology, 84(1), 234-252.

Forsman, L., \& Johnson, M. (1996). Dimensionality and validity of two scales measuring different aspects of self-esteem. Scandinavian Journal of Psychology, 37(1), 1-15.

Franks, D. D., \& Marolla, J. (1976). Efficacious action and social approval as interacting dimensions of self-esteem: A tentative formulation through construct validation. Sociometry, 39(4), 324-341.

Freyler, A., Köhegyi, Z., Köteles, F., KökÖnyei, G., \& BÁrdos, G. (2013). Modern health worries, subjective somatic symptoms, somatosensory amplification, and health anxiety in adolescents. Journal of Health Psychology, 18(6), 773-781.

Gillath, O., Bunge, S. A., Shaver, P. R., Wendelken, C., \& Mikulincer, M. (2005). Attachment style differences in the ability to suppress negative thoughts: Exploring the neural correlates. NeuroImage, 28(4), 835-847.

Gudjonsson, H. G., \& Sigurdsson, J. F. (2003). The relationship of compliance with coping strategies and self-esteem. European Journal of Psychological Assessment, 19(2), 117123.

Gyollai, Á., Simor, P., Köteles, F., \& Demetrovics, Zs. (2011). The psychometric properties of the Hungarian version of the short Positive and Negative Affect Scale (PANAS). Neuropsychopharmacologia Hungarica, 13(2), 73-79.

Hallsten, L., Josephonon, M., \& Torgén, M. (2005). Performance-based self-esteem: A driving force in burnout process. Arbete och hälsa, 2005:4, Stockholm: National Institute for Working Life, Sweden.

HARTER, S. (1985). Competence as a dimension of self-evaluation: Toward a comprehensive model of self-worth. In R. LEAHY (Ed.), The development of self (55-122). San Diego, CA: Academic Press.

Hewitt, P. L., \& Flett, G. L. (1991). Perfectionism in the self and social contexts: Conceptualisation, assessment, and association with psychopathology. Journal of Personality and Social Psychology, 60(3), 456-470.

Hill, C. A. (1987). Affiliation motivation: people who need people but in different ways. Journal of Personality and Social Psychology, 52(5), 1008-1018.

Johnson, M. (1997). On the dinamics of self-esteem. Empirical validation of basic-self esteem and earning self-esteem. PhD Dissertation. Stockholm University Department of Psychology. 
Johnson, M. (1998). Self-esteem stability: The importance of basic self-esteem and competence strivings for the stability of global self-esteem. European Journal of Personality, 12(2), 103-116.

Johnson, M. (2002). The importance of self-attitudes for Type A-B, externality-internality and health status. Personality and Individual Differences, 33(5), 777-789.

JoHnson, M. (2010). Depressive styles, self-esteem structure, and health: A dynamic approach to vulnerability in self-criticism and dependency. Individual Differences Research $8(1), 45-66$.

Johnson, M., \& Forsman, L. (1995). Competence strivings and self-esteem: An experimental study. Personality and Individual Differences, 19(4), 417-430.

Johnson, M., \& Blom, V. (2007). Development and validation of two measures of contingent self-esteem. Individual Differences Research, 5(4), 300-328.

Johnson, M., PaAnanen, M. L., Rahinantti, P., \& Hannonen, P. (1997). Depressed fibromyalgia patients are equipped with an emphatic competence dependent self-esteem. Clinical Rheumatology, 16(6), 485-491.

Johnson, M., \& Patching, G. R. (2013). Self-esteem dynamics regulate the effects of feedback on ambition. Individual Differences Research, 11(2), 44-58.

Joiner, JR., T. E., \& Metalsky, G. I. (2001). Excessive reassurance-seeking: Delineating a risk factor involved in the development of depressive symptoms. Psychological Science, 12(5), 371-378

KISS P. (2009). Az önbecsülés, elégedettség és identitás személyes és társadalmi vetületei. In Kiss P. (szerk.), Emberi kapcsolatok és társadalmi nézetek kérdőív skáláinak megbizhatósági és érvényességi vizsgálata. Budapest: Eötvös Kiadó.

Koivula, N., Hassmén, P., \& Fallby, J. (2002). Self-esteem and perfectionism in elite athletes: Effects on competitive anxiety and self-confidence. Personality and Individual Differences, 32(5), 865-875.

KopP M. és FóRIS N. (1995). A szorongás kognitív viselkedésterápiája. Budapest: Végeken sorozat.

Köteles, F., \& BÁRdos, G. (2011). What makes us sicker? An experimental study of nonspecific adverse drug effects. Clinical and Experimental Medical Journal, 5(4), 203-215.

Köteles, F., \& Ferentzi, E. (2012). Ethical aspects of clinical placebo use what do laypeople think? Evaluation \& the Health Professions, 35(4), 462-476.

KÖTELES, F., \& SiMOR, P. (2013). Modern health worries, somatosensory amplification and subjective symptoms: A longitudinal study. International Journal of Behavioral Medicine, 20(1), 38-41.

Köteles, F., \& Simor, P. (2014a). Somatic Symptoms and holistic thinking as major dimensions behind modern health worries. International Journal of Behavioral Medicine, 869-876.

KÖTEles, F., \& Simor, P. (2014b). Modern health worries, somatosensory amplification, health anxiety and well-being: A cross-sectional study. European Journal of Mental Health, 9, 20-33.

Köteles, F., Szemerszky, R., Freyler, A., \& BÁRdos, G. (2011). Somatosensory amplification as a possible source of subjective symptoms behind modern health worries. Scandinavian Journal of Psychology, 52(2), 174-178.

NeFF, K. D. (2003). The development and validation of a scale to measure SelfCompassion. Self and Identity, 2, 223-250. 
NefF, K. D. (2011). Self-Compassion, self-esteem, and well-being. Social and Personality Psychology Compass, 5(1), 1-12.

NefF, K. D., \& VONK, R. (2009). Self-compassion versus global self-esteem: Two different ways of relating to oneself. Journal of Personality, 77(1), 23-50.

Pincus, A. L., \& Gurtman, M. B. (1995). The three faces of interpersonal dependency: Structural analyses of self-report dependency measures. Journal of Personality and Social Psychology, 69(4), 744-758.

Pincus, A. L., \& WiLsON, K. R. (2001). Interpersonal variability in dependent personality. Journal of Personality, 69 (2), 223-251.

Rogers, C. (1951). Client-centered therapy. Boston: Mifflin Company.

Rosenberg, M. (1965). Society and the adolescent self-image., Princeton, NJ: Princeton University Press.

RyAN, R. M., \& DECI, E. L. (2000). Self-determination theory and the facilitation of intrinsic motivation, social development, and well-being. American Psychologist, 55(1), 68-78.

SÁGi A., KÖTEles F. és V. Komlósi A. (2013). Az Önmagunk iránt érzett együttérzés (Önegyüttérzés) skála magyar változatának (SCS-H) pszichometriai jellemzői. Pszichológia, 4, 295-313.

SÁGi A., Szekeres Zs. és Köteles F. (2012). Az aerobik pszichológiai jólléttel, önértékeléssel, valamint testi tudatossággal való kapcsolatának empirikus vizsgálata női mintán. Mentálhigiéné és Pszichoszomatika, 13(2), 271-293.

Scheier, M. F., \& Carver, C. S. (1985). Optimism, coping, and health: Assessment and implications of generalized outcome expectancies. Health Psychology, 4(3), 219-247.

Scheier, M. F., Carver, C. S., \& Bridges, M. W. (1994). Distinguishing optimism from neuroticism (and trait anxiety, self-mastery, and self-esteem): A reevaluation of the Life Orientation Test. Journal of Personality and Social Psychology, 67(6), 1063-1078.

Sipos K., Sipos M. és Spielberger, C. D. (1994). A State-Trait Anxiety Inventory (STAI) magyar változata. In Mérei F. és SzAKÁcs F. (szerk.), Pszichodiagnosztikai vademecum 2 (123-148). Budapest: Nemzeti Tankönyvkiadó.

Spielberger, C. D., Gorsuch, R. L., \& Lushene, R. E. (1970). Manual for the State-Trait Anxiety Inventory. Palo Alto, CA: Consulting Psychologists Press.

Stauder A. és Konkolÿ Thege, B. (2006). Az észlelt stressz kérdőív (PSS) magyar verziójának jellemzői. Mentálhigiéné és Pszichoszomatika, 7(3), 203-216.

Susánszky É., Konkolÿ Thege B., STAuder A. és Kopp M. (2006). A WHO Jól-lét Kérdőív rövidített (WBI-5) magyar változatának validálása a Hungarostudy 2002 Országos Lakossági Egészségfelmérés alapján. Mentálhigiéné és Pszichoszomatika, 7(3), 247-255.

V. KomLósi A. (2007). Napjaink önbecsülés-kutatásainak áttekintése. Önbecsülés és/vagy önelfogadás? In DemeTrovics Zs., KÖKÖNYEI Gy. és OLÁH A. (szerk.), Személyiség-lélektantól az egészségpszichológiáig. Tanulmányok Kulcsár Zsuzsanna tiszteletére (20-46). Budapest: Trefort Kiadó.

Watson, D., Clark, L. A., \& Tellegen, A. (1988). Development and validation of brief measures of positive and negative affect: The PANAS scales. Journal of Personality and Social Psychology, 54(6), 1063-1070. 


\title{
VALIDATION AND PSYCHOMETRIC CHARACTERISTICS OF THE HUNGARIAN VERSION OF THE CONTINGENT SELF-ESTEEM SCALE
}

\author{
SÁGI, ANDREA
}

Background: Self-esteem is a fundamental psychological need, but its certain subtypes may have not only good, but also harmful effects on mental health. Contingent self-esteem arises from low basic selfesteem and different self-validation needs (such as competence and relation). Contingent self-esteem is negatively related to indicators of mental health and positively connected to various maladaptive psychological characteristics.

Aim: Development, psychometric evaluation, and questionnaire-based validation of the Hungarian version of the Contingent Self-Esteem Scale (CSES-H) using independent samples.

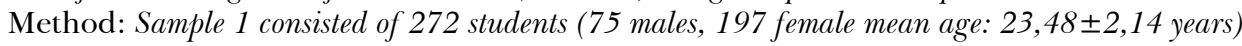
who completed questionnaires (Contingent Self-Esteem Scale - CSES-H; Rosenberg Self-Esteem Scale - RSES; Self-Compassion Scale - SCS-H; Spielberger Trait Anxiety Scale - STAI-T; Beck Depression Inventory - BDI and Life Orientation Test Revisited - LOT-R). The questionnaires were completed again by 153 participants one month later.

In the sample 2, 162 individuals practicing dance, $(52$ males and 110 females, mean age: $28,5 \pm 8,59$ years) and 208 females practicing aerobic (mean age: 28,4 $\pm 8,46$ years) completed questionnaires (CSES-H; RSES; WHO-Five Well-being Index, WHO-5 and Positive and Negative Affectivity Schedule, PANAS).

Results: The Contingent Self-Esteem Scale showed good internal consistency (between 0,72 and 0,91) and test-retest reliability (0,74-0,79), and the confirmatory factor analyises indicated an acceptable fit. A negative relationship to global self-esteem, self-compassion, dispositional optimism and wellbeing were found, while correlations with trait anxiety, depression and negative affectivity were positive.

Conclusion: The Hungarian version of the Contingent Self-Esteem Scale shows acceptable psychometric properties.

Key words: contingent self-esteem, contingent self-esteem scale, psychometric characteristics 